Case Reports
in Dermatology
Case Rep Dermatol 2021;13:103-105

DOI: $10.1159 / 000512714$

Published online: February 11, 2021
(C) 2021 The Author(s)

Published by S. Karger AG, Basel www.karger.com/cde

This article is licensed under the Creative Commons Attribution-NonCommercial 4.0 International License (CC BY-NC) (http://www.karger.com/Services/OpenAccessLicense). Usage and distribution for commercial purposes requires written permission.

\title{
Geophilic Tinea Profunda after a Stay at a Swiss Lake: A Case Report
}

\author{
Matthias Walther ${ }^{\mathrm{a}} \quad$ Deborah Leuthard ${ }^{\mathrm{b}}$ \\ aSkinmed - Clinic for Dermatology, Aarau, Switzerland; 'bepartment of Dermatology, \\ University Hospital Zurich, Zurich, Switzerland
}

\section{Keywords}

Nannizzia gypsea $\cdot$ Tinea profunda $\cdot$ Mosquito bite $\cdot$ Clinical mimics $\cdot$ Diagnostic delay

\begin{abstract}
Cutaneous infections with Nannizzia gypsea in Switzerland are very rare (only about $0.2 \%$ of all dermatophyte infections). We present the case of an impressive tinea profunda on the upper arm of a 53-year-old woman. In our patient, the source of infection was probably the sand and soil at a Swiss lake. This case report shows the importance of a correct diagnostic workup, as the infection can mimic an inflammatory dermatosis like psoriasis or eczema and thus lead to a diagnostic and therapeutic delay.

(C) 2021 The Author(s)

Published by S. Karger AG, Basel
\end{abstract}

\section{Case Presentation}

A 53-year-old female patient presented with a slightly red, partially hypopigmented, pruritic scaly plaque with recurrent pustules on her right upper arm in September 2019.

The onset of this new, initially bright red lesion was about 2 months prior to the first consultation (Fig. 1). She described first skin signs developing a few days after a mosquito bite during a visit to a public swimming area at a local lake, where she also had been swimming. No other triggers such as gardening, pets, or travel were identified.

Her family doctor suspected eczema and prescribed therapy with topical clobetasol for more than 6 weeks. According to the patient, the lesion became more intensely erythematous but was less symptomatic during this therapy with topical corticosteroids. However, there was no effect on the size of the plaque nor the development of new pustules.

\begin{tabular}{ll}
\hline & Matthias Walther \\
Herzogstrasse 10 \\
CH-5000 Aarau (Switzerland) \\
matthias.walther@bluewin.ch
\end{tabular}




\section{Case Reports in Dermatology}

Case Rep Dermatol 2021;13:103-105

DOI: 10.1159/000512714

C 2021 The Author(s). Published by S. Karger AG, Basel www.karger.com/cde

Walther and Leuthard: Geophilic Tinea Profunda after a Stay at a Swiss Lake: A Case Report

On her first visit to our clinic, we took a deep skin biopsy for histological and polymerase chain reaction (PCR) analysis (fungus, mycobacteria). Histology showed a deep inflammatory infiltrate mainly consisting of neutrophil granulocytes; there was no granuloma formation nor any positivity in PAS (periodic acid Schiff) staining. A few days later, PCR analysis revealed growth of Nannizzia gypsea. This geophilic fungus is often isolated in soil or sand, can rarely cause intensely inflammatory ringworm lesions (like in our patient), and is more often seen in women [1]. The analysis for mycobacteria remained negative.

The patient was then treated with oral itraconazole $100 \mathrm{mg}$ daily for 14 days. Topically she applied a ciclopirox cream twice a day.

Two weeks after completing this treatment, the original plaque presented slightly hypopigmented without any redness, scaling, or pustules.

In a follow-up consultation 2 months later, all skin manifestations had almost completely disappeared, except for a minimal central atrophy.

\section{Discussion}

The source of infection remains unclear. Possibly it was the contact with sand and soil at the lake. Infection through a mosquito bite has so far not been described, although transmission through domestic animals is possible [1,2]. Souza et al. [3] report that infections with Nannizzia gypsea depend on the specific virulence of the fungus, low resistance of the host, and previous skin lesions. In our patient, the mosquito bite might have led to a small skin lesion allowing the fungus to penetrate the skin. There are no signs of an impaired immune response in our patient.

Since the infection can mimic an inflammatory dermatosis like psoriasis or eczema, there is usually a delay in diagnosis of about 3.5 months $[3,4]$. In our patient, the delay in diagnosis was about 8 weeks.

The infection with Nannizzia gypsea is generally rare [2,4]. The prevalence depends on climate and geographical conditions and therefore varies from country to country (Switzerland $0.2 \%$, Egypt up to $20.9 \%$ of all fungal infections) [4].

We thus encourage all clinicians to be aware of a deep fungal infection and take a skin biopsy for further analysis if an inflammatory, pruritic skin lesion repeatedly shows pustules and does not respond to potent topical corticosteroids.

\section{Acknowledgments}

We would like to thank the patient for her contribution to the publication.

\section{Statement of Ethics}

The patient in this case report has given written informed consent to the publication of her case detail. Research was conducted ethically in accordance with the World Medical Association Declaration of Helsinki.

\section{Karger'=}




\section{Case Reports in Dermatology}

\begin{tabular}{l|l}
\hline Case Rep Dermatol 2021;13:103-105 \\
\hline DOI: 10.1159/000512714 & $\begin{array}{l}\text { C 2 2021 The Author(s). Published by S. Karger AG, Basel } \\
\text { www.karger.com/cde }\end{array}$ \\
\hline
\end{tabular}

Walther and Leuthard: Geophilic Tinea Profunda after a Stay at a Swiss Lake: A Case Report

\section{Conflict of Interest Statement}

The authors have no conflicts of interest to declare.

\section{Funding Sources}

The authors have no funding sources to declare.

\section{Author Contributions}

All authors have seen and approved the final version of the manuscript and have contributed significantly to the work.

\section{References}

1 Ginter G. Okologie, Epiderniologie und klinische Symptomatik von Microsporum gypseum-Infektionen [Ecology, Epidemiology and Clinical Symptomatology of Infections Due to Microsporum gypseum]. Mycoses. 1989;32(10):531-5.

2 Chmel L, Buchvald J. Ecology and transmission of Microsporum gypseum from soil to man. Sabouraudia. 1970 Aug;8(2):149-56.

3 Souza BD, Sartori DS, Andrade C, Weisheimer E, Kiszewski AE. Dermatophytosis caused by Microsporum gypseum in infants: report of four cases and review of the literature. An Bras Dermatol. 2016 NovDec;91(6):823-5.

4 Dolenc-Voljč M, Gasparič J. Human Infections with Microsporum gypseum Complex (Nannizzia gypsea) in Slovenia. Mycopathologia. 2017 Dec;182(11-12):1069-75.

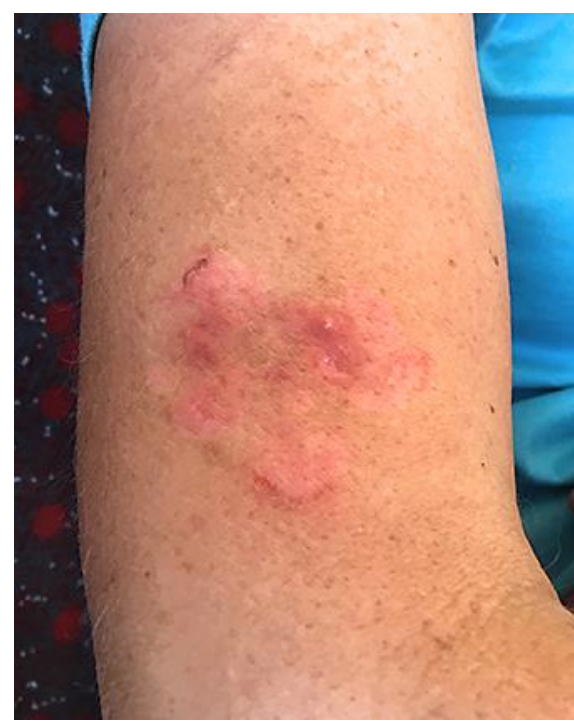

Fig. 1. Lesion before antifungal treatment (repetitive pustules) 